\title{
PENERAPAN RESTORATIVE JUSTICE DALAM PENCEGAHAN TERJADINYA LABELING TERHADAP ANAK PELAKU TINDAK PIDANA DI BANDAR LAMPUNG
}

\section{IMPLEMENTATION OF RESTORATIVE JUSTICE IN PREVENTION OF LABELING OF CHILDREN CRIMINAL OFFENDER AT THE BANDAR LAMPUNG}

\author{
Erna Dewi ${ }^{1}$, Damanhuri Warganegara ${ }^{2}$ \\ Fakultas Hukum Universitas Lampung \\ Email: Email: ernadewi00@yahoo.co.id
}

Dikirim 22 April 2021, Direvisi 12 Juni 2021, Disetujui 29 Juli 2021

\begin{abstract}
Abstrak: Proses peradilan pidana anak wajib mengutamakan pendekatan Restorative Justice, pada Pasal 8 Ayat (3) huruf c Undang-Undang Nomor 11 Tahun 2012 tentang Sistem Peradilan Pidana Anak menyebutkan proses Diversi wajib memperhatikan penghindaran stigma negatif atau Labeling. Permasalahan dalam tulisan ini adalah bagaimana penerapan Restorative Justice dalam pencegahan terjadinya Labeling terhadap anak, serta apa saja faktor penghambat penerapan Restorative Justice tersebut. Penelitian ini merupakan penelitian yuridis normatif dan yuridis empiris menggunakan data primer dan sekunder. Metode pengumpulan data menggunakan metode wawancara. Analisis data dilakukan dengan bahan kepustakaan secara kualitatif. Hasil penelitian dan pembahasan fakta yang ada di lapangan Restorative Justice atau Diversi terbagi menjadi dua, antara lain Diversi tidak berdasarkan hukum dan Diversi berdasarkan hukum. Restorative Justice dapat digunakan dalam pencegahan terjadinya Labeling terhadap anak untuk menghindari anak dari proses peradilan secara formal dan dapat kembali ke lingkungan sosial. Disarankan supaya orang tua, keluarga, serta masyarakat hendaknya membimbing dan mengawasi anak sehingga dapat tumbuh sesuai kodrat anak dan untuk mengantisipasi potensi terjadinya tindak pidana yang dilakukan oleh anak. Bagi kepolisian hendaknya mengadakan kerjasama dengan instansi terkait untuk melakukan sosialisasi tentang pentingnya mencegah Labeling khususnya terhadap anak pelaku tindak pidana dengan Restorative Justice atau Diversi dikalangan masyarakat serta selalu mengutamakan Restorative Justice sebagai salah satu alternatif dari pelaksanaan pidana penjara sehingga mencegah terjadinya Labeling terhadap anak.
\end{abstract}

Kata kunci: Restorative Justice, Labeling, Anak, Tindak Pidana.

Abstract: The juvenile criminal justice process must prioritize the Restorative Justice approach, in Article 8 Paragraph (3) letter c of Law Number 11 of 2012 concerning the Juvenile Criminal Justice System states that the Diversion process must pay attention to the avoidance of negative stigma or labeling. The problem in this research is the application of Restorative Justice in preventing the occurrence of labeling of children, as well as what are the inhibiting factors for the application of Restorative Justice. This research is a normative and empirical juridical research using primary and secondary data. The data collection method uses the interview method. Data analysis was carried out with qualitative literature. The results of research and discussion of facts in the field of Restorative Justice or Diversion are divided into two.. Restorative Justice can be used in preventing the occurrence of labeling of children to prevent children from formal justice processes and to return to the social environment. The inhibiting factor is the factor of the victim's family who wants the case to continue to be processed through the judiciary, the difficulty of being invited to a Diversion meeting as well as the mode of extortion against the perpetrator, the legal substance factor, legal structure, and legal culture. It is recommended that parents, families, and communities should guide and keep to watch the children so that they can grow according to the nature of the child and to anticipate the potential for criminal acts committed by children. The police should collaborate with related agencies to disseminate the importance of preventing labeling, especially for child perpetrators of criminal acts with Restorative Justice or Diversion among the community and always prioritizing Restorative Justice as an alternative to imprisonment so as to prevent labeling of children.

Keywords: Restorative Justice, Labeling, Child, Criminal Act 


\section{PENDAHULUAN}

Anak merupakan penerus bangsa karena dipundaknya terletak tugas bangsa yang belum terselesaikan oleh generasigenerasi sebelumnya. Pada saat ini mungkin anak belum bermakna apa-apa. Akan tetapi kedepannya, anak tersebutlah yang berperan utama menentukan arah dari bangsa dan negara Indonesia yang tercinta ini. Anak juga merupakan salah satu sumber daya manusia yang memiliki peranan yang sangat penting bagi pembangunan dan untuk masa depan di suatu negara. Anak memiliki karakteristik yang berbeda dengan orang dewasa, yang dalam hal ini menjadi acuan dalam melihat hak dan kewajiban seorang anak yang akan mempengaruhi kedudukannya di hadapan hukum. Undang-Undang Nomor 11 Tahun 2012 tentang Sistem Peradilan Pidana Anak juga disebutkan bahwa anak merupakan amanah dan karunia Tuhan Yang Maha Esa yang memiliki harkat dan martabat sebagai manusia seutuhnya. Anak sebagai salah satu sumber daya manusia dan merupakan generasi penerus bangsa sudah selayaknya mendapatkan perhatian khusus, baik dari orang tua, masyarakat dan pemerintah. Hal ini bertujuan dalam rangka pembinaan anak untuk mewujudkan sumber daya manusia yang tangguh serta berkualitas.

Selain itu, kepentingan anak harus dijadikan dasar pedoman oleh mereka yang bertanggung jawab terhadap pendidikan dan bimbingan anak yang bersangkutan, dan tentu saja pemegang utama dari tanggung jawab tersebut yakni orang tua yang harus menjaga dan menghormati hak dari anaknya menurut Maidin Gultom setiap anak harus mendapatkan pembinaan dari sejak dini, anak perlu mendapat kesempatan yang seluas-luasnya untuk dapat tumbuh dan berkembang, karena pada masa kanakkanak merupakan periode pembentukan watak, kepribadian, dan karakter seiring berjalannya waktu dan dalam kenyataannya yang telah terjadi, dewasa ini kejahatan atau perbuatan pidana yang telah terjadi di dalam masyarakat tidak hanya dilakukan oleh orang dewasa, tetapi juga banyak dilakukan oleh anak-anak. Perbuatan pidana adalah perbuatan oleh suatu aturan hukum dilarang dan diancam pidana. ${ }^{3}$ Kemudian kejahatan merupakan suatu fenomena yang kompleks yang dapat dipahami dari berbagai sisi yang berbeda ${ }^{4}$, khususnya bagi kejahatan yang dilakukan oleh anak. Pelaksanaan hukuman akibat dari tindak pidana yang dilakukan oleh anak tesebut tentunya sangat berbeda dengan yang dilakukan oleh orang dewasa. Pada umumnya, perilaku anak yang melakukan tindak pidana sering dikategorikan sebagai anak nakal atau anak yang melakukan pelanggaran hukum, yang dalam Undang-Undang disebut dengan anak yang berkonflik dengan hukum. Pasal 1 Ayat (3) Undang-Undang Nomor 11 Tahun 2012 tentang Sistem Peradilan Pidana Anak menyebutkan "Anak yang Berkonflik dengan Hukum yang selanjutnya di sebut Anak adalah anak yang telah berumur 12 (dua belas) tahun, tetapi belum berumur 18 (delapan belas) tahun yang di duga melakukan tindak pidana". Anak yang berkonflik dengan hukum ini atau anak sebagai pelaku tindak pidana disebut dengan anak yang delikuen atau dalam hukum pidana dikatakan sebagai Juvenile Delinquency. Romli Atmasasmita berpendapat bahwa Juvenile Delinquency adalah setiap perbuatan atau tingkah laku seorang anak di bawah umur 18 Tahun dan belum kawin yang merupakan pelanggaran terhadap norma-norma hukum yang berlaku serta dapat membahayakan perkembangan pribadi anak. Perbuatan melanggar hukum yang dilakukan oleh sebagian besar anakanak biasanya berawal dari perbuatan yang pada awalnya hanya sebatas kenakalan remaja, dan pada akhirnya menjurus pada suatu perbuatan kriminal yang membutuhkan penanganan hukum secara serius juga. Dalam upaya penanggulangan tindak pidana yang dilakukan oleh anak tentunya harus menggunakan metode yang sifatnya rehabilitasi daripada bersifat menghukum.

Berkaitan dengan pembinaan dan perkembangan kehidupan anak, diperlukan pula sarana dan prasarana hukum yang mengantisipasi segala permasalahan yang timbul. Sarana dan prasarana yang 
dimaksud menyangkut kepentingan anak maupun yang menyangkut penyimpangan sikap dan perilaku yang menjadikan anak terpaksa berhadapan dengan hukum atau dihadapkan ke muka pengadilan.

Selain dari itu, sarana hukum ini bertujuan untuk mengantisipasi stigma atau cap jahat dan nakal yang ditimbulkan ketika anak melakukan perbuatan pidana atau berhadapan dengan hukum, sekaligus merehabilitasi dan memasyarakatkan kembali anak tersebut. Perlakuan khusus terhadap anak pelaku tindak pidana yaitu tidak lain untuk memberikan perlindungan kepada mereka khususnya hak-hak yang patut dimiliki sehingga anak dapat hidup, tumbuh dan berkembang dan akan terwujud kelangsungan hidup generasi di masa depan yang berkualitas, sehat, cerdas, berakhlak mulia dan sejahtera Secara umum kebijakan kriminal yang digunakan untuk menanggulangi pelaku tindak pidana dapat dibagi menjadi dua, yaitu kebijakan menggunakan sarana hukum pidana (Penal Policy), dan dengan menggunakan sarana diluar hukum pidana (Non-Penal Policy). Proses yang diberlakukan terhadap Anak yang melakukan suatu perbuatan tindak hendaknya lebih menekankan pada sarana non-penal dalam menyelesaikan perkaranya. Diberlakukannya sarana non-penal juga berarti kebutuhan dalam penanggulangan kenakalan anak dapat berorientasi untuk mencapai kondisi yang kondusif dengan mengkaji mengenai penyebab timbulnya kenakalan anak, yang nantinya akan digunakan untuk menentukan penerapan kebijakan dalam menangani anak yang melakukan tindak pidana, yaitu dengan suatu penyelesaian yang disebut Restorative Justice. Pasal 5 Ayat (1) Undang-Undang Nomor 11 Tahun 2012 tentang Sistem Peradilan Pidana Anak juga menjelaskan bahwa sistem peradilan pidana anak wajib mengutamakan pendekatan Keadilan Restoratif. Restorative Justice ini merupakan suatu alternatif yang juga populer di berbagai belahan dunia khususnya untuk penanganan anak yang bermasalah dengan hukum karena menawarkan solusi yang efektif. Restorative Justice bertujuan untuk memberdayakan para korban, pelaku, keluarga, dan masyarakat untuk memperbaiki suatu perbuatan. melawan hukum dengan menggunakan kesadaran dan memberi pelajaran sebagai landasan untuk memperbaiki kehidupan bermasyarakat yang menjelaskan bahwa konsep Restorative Justice pada dasarnya mudah untuk dipahami hakikatnya. Restorative Justice merupakan teori keadilan yang menekankan pada suatu pemulihan kerugian yang disebabkan oleh perbuatan pidana. Restorative Justice dalam sistem peradilan pidana anak merupakan bagian dari implementasi Diversi. Data dari Direktorat Jendral Pemasyarakatan memperlihatkan jumlah anak yang berada di Lembaga Pembinaan Khusus Anak (LPKA) Kelas II Bandar Lampung pada Tahun 2019 dan 2020 menunjukkan jumlah yang cenderung banyak. Pada awal Tahun 2019 jumlah anak di LPKA adalah sebanyak 195 orang, kemudian pada akhir Tahun 2019 berjumlah 159 orang. Lalu pada awal Tahun 2020 jumlah anak di LPKA sebanyak 150 orang dan pada bulan Desember Tahun 2020 berjumlah sebanyak 90 orang. Dalam data tersebut, dapat disimpulkan bahwa di provinsi Lampung khususnya di LPKA Kelas II Bandar Lampung, terdapat tahanan dan narapidana anak yang jumlahnya tidak sedikit dan dikhawatirkan di masa yang akan datang jumlah tersebut juga akan meningkat yang mana mengakibatkan LPKA tersebut berpotensi Over Capacity, sehingga diperlukan metode yang tepat untuk mencegah terjadinya fenomena tersebut Anak yang berkonflik dengan hukum menjadi perhatian khusus dalam masyarakat yang memandang bahwa perilaku-perilaku yang dilakukan anak tersebut tidak seharusnya diperbuatnya sehingga memunculkan stigma atau label terhadap anak. Labeling adalah proses memberi stigma atau label kepada seseorang. Label yakni sebuah definisi yang ketika diberikan kepada seseorang, maka akan menjadi identitas diri orang itu, serta menjelaskan seperti apakah tipe orang tersebut. Dengan pemberian label pada diri seseorang, orang lain akan cenderung menilai dia bukan pada perilakunya satu 
persatu akan tetapi secara keseluruhan kepribadiannya dinilai berdasarkan label tersebut. Bagi anak-anak pengalaman mendapatkan label tertentu (terutama yang negatif) memicu pemikiran bahwa dirinya ditolak. Pemikiran bahwa dirinya ditolak dan kemudian dibarengi oleh sikap penolakan yang sesungguhnya, dapat menghancurkan kemampuan berinteraksi, mengurangi rasa harga diri, dan berpengaruh negatif terhadap kinerja seseorang dalam kehidupan sosial dan kehidupan kerjanya. Pasal 8 Ayat (3) huruf c Undang- Undang Nomor 11 Tahun 2012 tentang Sistem Peradilan Pidana Anak menyebutkan bahwa proses Diversi wajib memperhatikan penghindaran stigma negatif. Hal tersebut dirasa penting karena bagi anak penting untuk merasa bahwa dirinya berharga dan dicintai. Perasaan ini ditemukan olehnya lewat respon orangorang disekitarnya. Kalau respon orang disekitarnya positif tentunya tidak perlu dicemaskan akibatnya. Tetapi, adakalanya orang disekitar si anak tersebut, tidak dapat menahan diri sehingga menunjukkan respon-respon negatif seputar anak tersebut. Walaupun sesungguhnya orang tersebut tidak bermaksud buruk dengan responresponnya, namun tanpa disadari hal-hal yang dikatakan, sikap dan responnya, masuk dalam hati dan pikiran seorang anak dan berpengaruh dalam kehidupannya. Terutama dalam pembentukan identitas si anak tersebut.

Berdasarkan isu hukum yang telah diuraikan, penulis melakukan kajian dan penelitian yang berjudul: " Penerapan Restorative Justice Dalam Pencegahan Terjadinya Labeling Terhadap Anak Pelaku Tindak Pidana di Bandar Lampung" Berdasarkan latar belakang di atas, permasalahan penelitian ini adalah:

1. Bagaimanakah penerapan Restorative Justice dalam pencegahan terjadinya Labeling terhadap anak pelaku tindak pidana di Bandar Lampung?

2. Apakah yang menjadi hambatan dalam menerapkan Restorative Justice sebagai pencegahan terjadinya Labeling terhadap anak pelaku tindak pidana di Bandar Lampung?

\section{METODOLOGI}

Penelitian ini merupakan penelitian yuridis normatif dan yuridis empiris menggunakan data primer dan sekunder. Metode pengumpulan data menggunakan metode wawancara. Analisis data dilakukan dengan bahan kepustakaan secara kualitatif.

\section{HASIL DAN PEMBAHASAN}

a. Penerapan Restorative Justice dalam Pencegahan Terjadinya Labeling Terhadap Anak Pelaku Tindak Pidana

Proses peradilan pidana bagi anak yang berkonflik dengan hukum yang secara khusus mempunyai tujuan yang penting untuk dicapai karena menyangkut kepentingan masa depan anak dan juga masyarakat yang di dalamnya memliki prinsip dari Restorative Justice. Pasal 1 butir 6 Undang-Undang Nomor 11 Tahun 2012 tentang Sistem Peradilan Pidana Anak menjelaskan Keadilan Restoratif adalah penyelesaian perkara tindak pidana dengan melibatkan pelaku, korban, keluarga pelaku/korban, dan pihak lain yang terkait untuk bersama-sama mencari penyelesaian yang adil dengan menekankan pemulihan kembali pada keadaan semula, dan bukan pembalasan. Keadilan Restoratif atau Restorative Justice tersebut memiliki tujuan untuk memberdayakan para korban, pelaku, keluarga, dan masyarakat untuk memperbaiki suatu perbuatan melawan hukum dengan menggunakan kesadaran dan memberi pelajaran sebagai landasan untuk memperbaikikehidupan bermasyarakat yang menjelaskan bahwa konsep Restorative Justice pada dasarnya mudah untuk dipahami hakikatnya. Restorative Justice sendiri merupakan suatu teori keadilan yang menekankan pada suatu pemulihan kerugian yang disebabkan dari perbuatan pidana.

Diah Gustiniati Maulani menjelaskan dalam perkembangan hukum pidana yang 
digunakan telah terjadi pergeseran paradigma dalam hal peradilan pidana anak, yang pada awalnya adalah Retributive Justice, kemudian berubah menjadi Rehabilitation, lalu yang terakhir berubah menjadi Restorative Justice. Pengalihan penyelesaian perkara berkaitan dengan anak ke luar jalur formal peradilan melalui Diversi membawa implikasi yuridis bagi Negara Indonesia untuk mengakomodir ketentuan Diversi tersebut dalam peraturan perundang- undangan anak di Indonesia. Dalam mewujudkan konsep Diversi sebagai instrumen dalam Restorative Justice pada Sistem Peradilan Pidana Anak berdasarkan UndangUndang Nomor 11 Tahun 2012 yaitu penyelesaian perkara tindak pidana dengan melibatkan pelaku, korban, keluarga pelaku/keluarga korban dan pihak lain yang terkait untuk bersama sama mencari penyelesaian yang adil dan bukan pembalasan dengan menekankan pemulihan kembali pada keadaan semula.

Penulis menyatakan bahwa lahirnya Undang-Undang Sistem Peradilan Pidana Anak memberi peneguhan dan manfaat yang sangat positif terkait dengan perlindungan hukum terhadap hak-hak anak di Indonesia. Undang-Undang inilah yang memperkenalkan suatu konsep yaitu Diversi yang bertujuan untuk memberikan perlindungan hukum terhadap anak yang berkonflik dengan hukum maupun anak yang menjadi korban tindak pidana, serta peran masyarakat yang pada umumnya sebagai sebuah bentuk pengalihan penyelesaian perkara anak dari proses peradilan ke proses di luar peradilan pidana demi mewujudkan suatu Keadilan Restoratif atau Restorative Justice.

Suswanto menyatakan bahwa kepolisian sebagai penegak hukum yang pertama dalam penanganan terhadap anak yang berkonflik dengan hukum sehingga salah satu cara yang dapat ditempuh dalam penanganan perkara pidana anak sangat penting menggunakan suatu proses penyelesaian perkara yaitu pendekatan Restorative Justice, yang dilaksanakan dengan cara pengalihan atau yang disebut Diversi. ${ }^{10}$ Berdasarkan penjelasan dari Pasal 7 Undang-Undang Nomor 11 Tahun 2012 tentang Sistem Peradilan Pidana Anak yang menyebutkan bahwa setiap perkara anak wajib diupayakan Diversi baik dalam tingkat penyidikan, penuntutan, dan pemeriksaan perkara.

Suswanto menyatakan bahwa sesuai dengan amanat Undang-Undang Nomor 11 Tahun 2012 tentang Sistem Peradilan Pidana Anak bahwa pada praktiknya penyidik kepolisian Polresta Bandar Lampung dalam menghadapi kasus tindak pidana yang dilakukan oleh anak, selalu menggunakan proses penyelesaian perkara melalui Restorative Justice atau Diversi dalam menyelesaikan kasus tindak pidana yang diancam dengan pidana penjara dibawah 7 (tujuh) tahun, dan juga bukan merupakan pengulangan tindak pidana sesuai pada Pasal 7 Ayat (2) Undang-Undang Nomor 11 Tahun 2012 tentang Sistem Peradilan Pidana Anak. Bahkan pada Tahun 2020 ini, Suswanto menjelaskan dalam kasus yang menyangkut anak yang berkonflik dengan hukum di daerah hukum Polresta Bandar Lampung yang tergolong usia dibawah 12 tahun, selalu berhasil menggunakan proses Diversi yang berujung perdamaian.

Hasil penelitian diketahui bahwa data yang diperoleh dari Penyidik Perlindungan Perempuan dan Anak (PPA) di daerah hukum Polresta Bandar Lampung bahwa pada Tahun 2020, jumlah kasus anak yang berkonflik dengan hukum sebanyak 38 kasus tindak pidana yang mayoritas seperti tindak pidana Pencurian, Pencabulan, Kekerasan, dan Perundungan. Kemudian Penyidik Perlindungan Perempuan dan Anak (PPA) di Polresta Bandar Lampung telah melakukan Diversi terhadap 21 anak dan yang berhasil terjadi kesepakatan Diversi ada sebanyak 15 anak meliputi 10 anak dikembalikan ke orang tua, sedangkan 5 
anak mengikuti diklat atau pendidikan dan juga pelatihan di lembaga pendidikan atau LPKS.

Penulis menyatakan bahwa dari data yang diperoleh tersebut, menggambarkan dalam penyelesaian tindak pidana anak ditingkat penyidikan di daerah hukum Polresta Bandar Lampung yang mana dari total perkara sebanyak 38 kasus tindak pidana yang terjadi, perkara yang melakukan proses Diversi hanya sebanyak 21 kasus tindak pidana. Total perkara sebanyak 17 kasus tindak pidana yang tidak melakukan proses Diversi karena diduga melakukan tindak pidana yang diancam dengan pidana penjara diatas 7 tahun, dan juga merupakan pengulangan tindak pidana. Kemudian dari total 21 kasus tindak pidana yang melakukan proses Diversi, yang berhasil terjadi kesepakatan Diversi sebanyak 15 kasus tindak pidana yang dikembalikan ke orang tua, mengikuti diklat atau pendidikan dan juga pelatihan di lembaga pendidikan atau LPKS. Total perkara sebanyak 6 kasus tindak pidana yang melakukan proses Diversi tetapi tidak terwujud kesepakatan Diversi dikarenakan pihak keluarga korban yang bersikeras menuntut agar pelaku anak tetap diproses sesuai hukum dan sulit diundang untuk dilakukan pertemuan Diversi, pihak keluarga korban untuk melakukan suatu modus pemerasan, dan lain sebagainya yang terpaksa menyebabkan perkara tersebut diproses menggunakan sistem peradilan pidana yang ada. Kemudian berdasarkan dari data tersebut, dapat dikatakan bahwa penyidik Polresta Bandar Lampung sebagai pihak yang melakukan pemeriksaan awal terhadap anak yang berkonflik dengan hukum dan dapat dikatakan telah berhasil dalam melakukan upaya-upaya penerapan Diversi dengan pertimbangan tindak pidana yang dilakukan diancam pidana penjara dibawah 7 tahun dan bukan merupakan pengulangan tindak pidana. Suswanto menjelaskan bahwa apabila penanganan dan penanggulangan yang salah terhadap anak sebagai pelaku tindak pidana, akan berdampak pada terganggunya suatu program atau sistem dalam rangka menyiapkan anak-anak tersebut sebagai generasi penerus bangsa yang unggul di masa depan. Apabila menempatkan anak pelaku tindak pidana di dalam proses peradilan formal, hal tersebut sudah pasti dapat memberikan dampak yang sangat buruk bagi perkembangan dan kehidupan anak serta berpotensi menimbulkan Labeling terhadap anak.

Dampak buruk berupa trauma psikis karena pemberian Labeling atau stigma negatif pada anak seperti "penjahat", dan hal-hal lain seperti dikeluarkan dari sekolah, dijauhi dan tidak memiliki teman, ditakuti dan dipandang sebelah mata oleh masyarakat, hal-hal buruk tersebut akan diterima anak apabila ditempatkan dalam sistem peradilan pidana formal yang berujung pemenjaraan. Hal ini berpotensi melanggar hak-hak asasi mereka, bahkan tidak jarang dijumpai, efek Labeling atau stigma negatif pada anak justru membuat mereka memiliki keterampilan kriminal luar biasa dan membuat mereka melakukan lagi perbuatan tindak pidana, karena dalam pikiran anak tersebut selalu mengatakan bahwa dirinya tidak lagi diterima dimasyarakat atau dimanapun, kegundahan hati tersebut yang sangat menghancurkan masa depan anak nantinya.

Menurut penulis, bahwa proses Diversi terbagi menjadi dua, yaitu Diversi tidak berdasarkan hukum dan Diversi berdasarkan hukum. Diversi tidak berdasarkan hukum yaitu Diversi bagi anak yang berkonflik dengan hukum yang belum berumur 12 tahun, dikenakan tindakan seperti proses Diversi wajib terwujud langsung dan anak dikembalikan kepada orang tuanya, ditempatkan pada organisasi sosial atau diserahkan kepada Negara. Sedangkan Diversi berdasarkan hukum yaitu Diversi bagi anak yang berkonflik dengan hukum yang telah berumur 12 
tahun, tetapi belum berumur 18 tahun yang diduga melakukan tindak pidana yang diancam dengan pidana penjara dibawah 7 tahun, dan juga bukan merupakan pengulangan tindak pidana sesuai pada Pasal 7 Ayat (2) Undang-Undang Nomor 11 Tahun 2012 tentang Sistem Peradilan Pidana Anak dan dapat dijatuhkan pidana apabila penyelesaian perkara anak tersebut tidak mencapai perdamaian atau tidak tercapainya kesepakatan Diversi. Pembedaan perlakuan tersebut didasarkan atas pertumbuhan dan perkembangan fisik, mental, sosiologis, dan psikologis.

Restorative Justice atau Diversi dapat digunakan dan membantu dalam pencegahan terjadinya Labeling terhadap anak yang berkonflik dengan hukum atau anak pelaku tindak pidana karena model Restorative Justice atau Diversi sendiri dimaksudkan untuk menghindari dan menjauhkan anak dari proses peradilan secara formal, sehingga dapat menghindari stigmatisasi negatif atau Labeling terhadap anak yang berkonflik dengan hukum dan diharapkan anak dapat kembali ke dalam lingkungan sosial secara wajar. Oleh karena itu, sangat diperlukan peran serta semua pihak dalam rangka mewujudkan hal tersebut. Proses itu harus bertujuan pada terciptanya suatu Keadilan Restoratif, baik bagi anak maupun bagi korban. Diversi merupakan suatu proses bahwa semua pihak yang terlibat dalam suatu tindak pidana tertentu bersama-sama mengatasi masalah serta menciptakan suatu kewajiban untuk membuat segala sesuatunya menjadi lebih baik dengan melibatkan korban, anak, dan masyarakat dalam mencari solusi untuk memperbaiki, rekonsiliasi, dan menentramkan hati yang tidak berdasarkan pembalasan. Pada penyelesaian perkara yang melibatkan masyarakat perlu pemberdayan masyarakat dengan berbagai kegiatan positif melalui tahapan yang meliputi tahap penyadaran(awerness), tahap pengkapasitasan (capacity building)dan pendayaan atau penguatan (empowerment) terhadap prilaku anak terutama terhadap anak yang bermasalah dengan hukum.

b. Faktor Penghambat Penerapan Restorative Justice sebagai Pencegahan Terjadinya Labeling Terhadap Anak Pelaku Tindak Pidana.

Penerapan Restorative Justice sebagai pencegahan terjadinya Labeling terhadap anak pelaku tindak pidana pada proses Penyidikan Perkara Anak, dalam hal ini Penyidik Perlindungan Perempuan dan Anak (PPA) Polresta Bandar Lampung sebagai penegak sebagai syarat terwujudnya suatu perlindungan hukum bagi anak dan anak yang berhadapan dengan hukum terhindar dari Labeling. Keberhasilan penerapan Restorative Justice terhadap anak dalam proses penyidikan di Polresta Bandar Lampung tidaklah semata-mata menyangkut ditegakkannya hukum yang berlaku, akan tetapi sangat tergantung pula dari faktor-faktor yang mempengaruhi pelaksanaan tercapainya penyelesaian perkara menggunakan proses tersebut.

Sistem peradilan pidana anak di Indonesia menganggap Restorative Justice tersebut tidak mudah untuk diimplementasikan untuk melaksanakan penegakan hukum untuk anak pelaku tindak pidana. Terdapat faktor-faktor penghambat terhadap upaya pelaksanaanya dalam sistem peradilan pidana anak Indonesia saat ini. Suswanto menjelaskan Polresta Bandar Lampung sendiri dalam menerapkan Restorative Justice sebagai pencegahan terjadinya Labeling terhadap anak pelaku tindak pidana mengalami hambatan-hambatan tersendiri yaitu sebagai berikut :

\section{Hambatan dari pihak keluarga korban}

Banyak kasus tindak pidana anak dengan anak sebagai korban, pihak keluarga korban bersikeras menuntut agar pelaku anak tetap diproses sesuai hukum. Mayoritas masyarakat terutama keluarga korban yang memandang bahwa 
anak yang berkonflik dengan hukum pun harus dihukum setimpal layaknya orang dewasa. Hal ini terjadi karena pihak keluarga korban tidak terima ketika anaknya terluka akibat tindak pidana yang dilakukan oleh pelaku. Hal ini menyulitkan penyidik dalam melakukan proses perdamaian terhadap kasus anak karena kuatnya pengaruh keluarga korban yang menentang proses Restorative Justice atau pada proses Diversi yang berdasarkan hukum.

Pihak keluarga korban pun juga sulit diundang untuk dilakukan pertemuan Diversi. Hal ini terjadi karena sebenarnya pihak keluarga korban menginginkan proses dilanjut di jalur pengadilan, sehingga ketika diundang untuk melakukan musyawarah tidak bisa hadir. Juga dalam hal telah dilakukan proses Diversi yang melibatkan beberapa pihak untuk mencapai mufakat, ternyata tidak tercapai kesepakatan. Hal ini mengakibatkan Restorative Justice yang diharapkan sebagai pencegahan terjadinya Labeling terhadap anak pelaku tindak pidana tersebut tidak berhasil.

2. Proses Diversi menimbulkan modus pemerasan

Proses Diversi atau Restorative Justice pada intinya ingin mencapai suatu kesepakatan yang berwujud perdamaian antara pelaku dengan korban. Pada kenyataannya, banyak kasus tindak pidana oleh anak yang mengakibatkan korban menderita sejumlah kerugian, baik itu kerugian materi maupun kerugian berupa luka fisik. Dalam beberapa kasus pada proses Diversi yang berdasarkan hukum bagi anak yang berkonflik dengan hukum yang telah berumur 12 tahun, tetapi belum berumur 18 tahun yang diduga melakukan tindak pidana, pihak keluarga korban tersebut akan meminta ganti kerugian dalam jumlah yang besar. Jumlah yang besar ini cenderung menjadi alat bagi pihak keluarga korban untuk melakukan suatu modus pemerasan, yang mana nominal ganti kerugian yang ditawarkan sering kali tidak dapat disanggupi oleh pihak pelaku. Tawar menawar terkait ganti kerugian ini yang dapat menghambat tercapainya kesepakatan Diversi atau Restorative Justice sebagai pencegahan terjadinya Labeling terhadap anak pelaku tindak pidana.

3. Hambatan dari segi substansi hukum, struktur hukum, dan kultur hukum.

Hambatan yang berkaitan dengan substansi hukum erat kaitannya dengan instrumen hukum yang akan diterapkan dalam kehidupan bermasyarakat, yang dalam hal ini akan diterapkan dan digunakan sebagai dasar dalam pelaksanaan proses Restorative Justice atau Diversi, yang secara nyata masih memiliki kelemahan, terutama mengenai batasan waktu yang ada yang diatur di dalam undang- undang, dan lain sebagainya. Kemudian hambatan yang berkaitan dengan struktur hukum yang dalam hal ini mengatur tentang mekanisme pelaksanaan Diversi tersebut harus mampu menjalankan hukum itu sendiri dan memberikan keadilan hukum secara proporsional, mekanisme pelaksanaan Diversi dapat terhambat karena kurangnya sumber daya manusia khususnya para aparat penegak hukum yang tetap memproses perkara anak dengan menggunakan sistem peradilan pidana dan tidak mengindahkan prinsip Restorative Justice sehingga penanganan terhadap anak yang berhadapan dengan hukum menjadi tidak maksimal.

Hambatan yang berkaitan dengan kultural yakni yang berkaitan dengan kultur hukum yang ada di masyarakat dan pandangan masyarakat terhadap perbuatan tindak pidana. Pengetahuan masyarakat mengenai hukum masih sangat minim maka hal ini menjadi kendala untuk melaksanakan proses Restorative Justice. Masyarakat masih banyak yang belum mengetahui dan menyadari arti penting anak agar terhindar dari proses peradilan untuk 
kepentingan masa depan anak tersebut, bahkan juga menilai siapapun harus mendapat balasan yang setimpal atas perbuatan pidana yang telah dilakukan, tidak terkecuali pelakunya adalah seorang anak. Selain itu juga terkadang masyarakat yang telah mengetahui anak tersebut telah melakukan tindak pidana cenderung untuk selalu memberi stigma "penjahat" dan sulit untuk melupakan hal tersebut. Penanganan perkara terhadap anak yang berkonflik dengan hukum pada akhirnya sangat melibatkan peran serta dukungan dari berbagai pihak, yaitu tidak hanya dari aparat penegak hukum tetapi juga partisipasi keluarga dan masyarakat. Orang tua juga tidak hanya mendampingi namun juga memberikan dukungan moral kepada anak. Restorative Justice atau Diversi dapat menjadi jalan untuk menghindarkan anak dari Labeling atau pemberian cap yang negatif Namun peran masyarakat juga sangat penting untuk mewujudkan Restorative Justice atau keadilan restoratif tersebut sehingga tidak terciptanya fenomena Labeling dan stigma sosial bagi anak yang berkonflik dengan hukum.

\section{KESIMPULAN}

Berdasarkan hasil penelitian dan pembahasan maka dapat disimpulkan sebagai berikut:

1. Proses Restorative Justice atau Diversi terbagi menjadi dua, antara lain Diversi tidak berdasarkan hukum yaitu Diversi bagi anak yang berkonflik dengan hukum yang belum berumur 12 tahun, dan Diversi berdasarkan hukum yaitu Diversi bagi anak yang berkonflik dengan hukum yang telah berumur 12 tahun, tetapi belum berumur 18 tahun yang diduga melakukan tindak pidana yang diancam dengan pidana penjara dibawah 7 tahun, dan bukan merupakan pengulangan tindak pidana sesuai pada Pasal 7 Ayat (2) Undang-
Undang Nomor 11 Tahun 2012 tentang Sistem Peradilan Pidana Anak. Restorative Justice dapat digunakan dalam pencegahan terjadinya stigmatisasi negatif atau Labeling terhadap anak pelaku tindak pidana yang dimaksudkan untuk menghindari dan menjauhkan anak dari proses peradilan secara formal dan diharapkan anak dapat kembali ke dalam lingkungan sosial secara wajar dan peran serta semua pihak dalam rangka mewujudkan hal tersebut sangat diperlukan.

2. Faktor-faktor yang dapat menjadi penghambat dalam penerapan Restorative Justice sebagai pencegahan terjadinya Labeling terhadap anak pelaku tindak pidana adalah faktor dari keluarga korban yaitu pihak keluarga korban yang menginginkan kasus diproses melalui jalur peradilan, sulitnya diundang untuk dilakukan pertemuan Diversi maupun adanya modus pemerasan terhadap pelaku, faktor substansi hukum, struktur hukum, dan kultur hukum dan lain sebagainya.

\section{SARAN}

1. Orang tua, keluarga, serta masyarakat hendaknya membina, membimbing dan mengawasi anak sehingga anak dapat tumbuh sesuai kodrat anak tersebut, dan kasus anak yang berhadapan dengan hukum tidak terjadi atau guna mengantisipasi potensi terjadinya tindak pidana yang dilakukan oleh anak.

2. Kepolisian hendaknya mengadakan kerjasama dengan instansi terkait untuk melakukan sosialisasi atau penyuluhan tentang pentingnya mencegah Labeling khususnya terhadap anak pelaku tindak pidana dengan Restorative Justice atau Diversi dikalangan masyarakat dan lebih baik dalam hal penyidikan serta selalu mengutamakan pelaksanaan Restorative Justice sebagai salah satu alternatif dari 
pelaksanaan pidana penjara sehingga mencegah terjadinya Labeling terhadap anak.

\section{DAFTAR PUSTAKA}

Achmad, Deni dan Firganefi. 2016. Pengantar Kriminologi dan Viktimologi, Bandar Lampung: Justice Publisher.

Atmasasmita, Romli. 1997. Peradilan Anak Di Indonesia, Bandung: Mandar Maju.

Direktur Rehabiilitasi Sosial Kementerian Sosial RI: jumlah Anak yang Berkonflik dengan Hukum pada Tahun 2019 dan 2020.

Gultom, Maidin. 2008. Perlindungan Hukum Terhadap Anak Dalam Sistem Peradilan Pidana Anak di Indonesia, Bandung: Refika Aditama.

Hartono, Sunarjati. 1991. Politik Hukum Menuju Satu Sistem Hukum Nasional, Bandung: Alumni.

Indonesia, Undang-Undang tentang Sistem Peradilan Pidana Anak, UU No. 11 Tahun 2012, LN No. 153 Tahun 2012, TLN No. 5332.

Indonesia, Undang-Undang tentang Kepolisian Negara Republik Indonesia, UU No. 2 Tahun 2002, LN No. 2 Tahun 2002, TLN No. 4168.

Maulani, Diah Gustiniati. 2016.

Diversi dan Restorative Justice Dalam Perspektif Penyelesaian Perkara Anak Yang Berkonflik Dengan Hukum.

Pradityo, Randi. 2016. Restorative Justice Dalam Sistem Peradilan Pidana Anak, Pusat Studi Pembaharuan Hukum Indonesia. Vol. 5, No. 3.

Rosidah, Nikmah. 2011. Asas-Asas Hukum Pidana, Semarang: Pustaka Magister.
Zulfikar Firman, dkk. 2020, Peningkatan Akses Pangan Bagi Masyarakat Marjinal Perkotaan Melalui Pelatihan Vertikal Farming dan Pertanian Organik di Desa Lengkong Kulon Tangerang. Jurnal Kelitbangan Vol.08 Nomor 01, April 2020. 